\title{
Genetic predisposition to ocular melanoma
}

\begin{abstract}
Uveal melanoma is the most common primary intraocular malignancy, with an annual incidence of 6 per million. The environmental factors known to increase the risk of cutaneous melanoma appear to be less important in ocular melanoma and it is conceivable that host factors have a greater impact. The coexistence of ocular and cutaneous melanoma in some patients suggests a predisposition to both types and implicates mutations in the CDKN2A gene in a proportion of these cases. An association between ocular melanoma and breast and/or ovarian cancer has also been reported and recent studies of breast cancer families strongly implicate $B R C A 2$ as a predisposition gene. Other more common genes predisposing to ocular melanoma may be of low penetrance. An example of a gene in this class is $M C 1 R$, which affects host response to ultraviolet radiation. Identification of genes conferring an increased risk of ocular melanoma should provide insights into the pathogenesis of this tumour. Furthermore, it offers an opportunity to identify individuals at a high risk who may benefit from targeted surveillance. At present the identification of such individuals is restricted to the small number belonging to BRCA2 families and those with the atypical mole syndrome.
\end{abstract}

Key words BRCA2, CDKN2, Genetics, Ocular melanoma

Uveal melanomas are the most common primary intraocular malignant tumour (incidence 6 per million per year; lifetime risk 1 in 2500). ${ }^{1-3}$ They differ substantially in their incidence and biological behaviour from cutaneous melanoma. ${ }^{1-6}$ In contrast to cutaneous melanoma, the peak incidence of uveal melanoma occurs between 50 and 70 years of age and metastases are common (related to histology and site). Half the patients developing uveal melanomas die of their disease within 15 years after treatment. ${ }^{4}$

Environmental, host and genetic factors involved in the pathogenesis of uveal melanoma have not been clearly defined. ${ }^{6-8}$ The role of sunlight as an environmental risk factor for uveal melanoma is controversial, ${ }^{9-17}$ although the tendency to develop uveal melanoma is greater in whites compared with blacks. ${ }^{5,6}$ There has been no evidence for an increase in eye cancer incidence or mortality over the last 20 years in any part of the world, even in countries such as Australia which have seen a rapid increase in cutaneous melanoma cases. ${ }^{9,10}$ Furthermore, there is little variation in the incidence of uveal melanoma within or between countries. ${ }^{12}$ It is therefore probable that host factors play a greater role in the development of ocular melanoma than in cutaneous melanoma.

Epidemiological evidence for a genetic predisposition to uveal melanoma

Silcock ${ }^{18}$ was the first to question whether there could be a hereditary basis for uveal melanoma when he reported a mother and daughter with the disease in 1892. Since then there have been over 50 further reports of ocular melanomas occurring within families. ${ }^{19,20}$ Some uveal melanomas are associated with neurofibromatosis ${ }^{21}$ or Gorlin's syndrome; ${ }^{22}$ however, the vast majority of familial cases reported are non-syndromic. Although the familial occurrence of uveal melanoma is rare there is strong statistical evidence that it is not coincidental. In a systematic survey of a series of patients with primary uveal melanoma, Singh et al. ${ }^{23}$ identified 17 kindreds with a firstdegree relative affected with primary uveal melanoma. The expected number of affected first-degree relatives was $0.81(R R=20.99 ; 95 \%$ CI, 12.2-33.6). The majority of the familial cases reported are one- or two-generation families and have only one affected member in addition to the proband. However, a few contain three or more cases of ocular melanoma and are compatible with the inheritance of an autosomal dominant gene with incomplete penetrance.

Individuals with a cancer predisposition tend to develop the disease at an earlier age, have bilateral involvement of paired organs and are at an increased risk of developing multiple primary cancers at different sites. The mean ages at diagnosis in familial and sporadic uveal melanomas reported by Canning and Hungerford ${ }^{19}$ were 42 and 56 years respectively. Several cases of bilateral melanoma of the uvea have been reported, including one with a documented family history of uveal melanoma. ${ }^{24-27}$
R.S. Houlston

Section of Cancer Genetics Institute of Cancer Research Sutton

Surrey SM2 5NG, UK

B.E. Damato

Ocular Oncology Service

Royal Liverpool University Hospital

Liverpool L7 8XP, UK

Dr R.S. Houlston

Section of Cancer Genetics Institute of Cancer Research Sutton

Surrey SM2 5NG, UK

Tel: $+44(0) 1816438901$

Fax: +44 (0)1816430257

e-mail: r.houlston@icr.ac.uk

Received: 15 June 1998

Accepted in revised form:

1 October 1998 
A number of inherited susceptibility genes tend to cause cancer at several sites. Any excess of cancer in relatives at sites other than the eye may therefore reflect in part the pleiotropic effects of an inherited predisposition. There are a number of anecdotal reports of uveal melanoma in association with other cancers. ${ }^{28-30}$ One of the most spectacular of these is a family first reported by Silcock, ${ }^{18}$ which has been the subject of a recent follow-up study. ${ }^{28}$ Three of eight individuals who developed uveal melanoma also developed breast cancer (bilateral breast cancer in one case). Similarly striking is a case of bilateral uveal melanoma in association with primary bilateral ovarian carcinoma reported by Mullaney et al. ${ }^{29}$ A relationship between ocular melanoma and other cancers is supported by some, ${ }^{20,32,34}$ but not all, ${ }^{31,33}$ systematic studies. In an analysis of 27 uveal melanoma families, Sing et al. ${ }^{20}$ found the risk of a second primary was increased 4 -fold. The most common malignancies observed in family members were breast, prostate and cutaneous melanoma. In a follow-up study of 32251 women with ovarian cancer the risk of ocular melanoma was increased 4 -fold. ${ }^{32}$ An increased risk of melanoma of the skin or eye has also been reported in a follow-up study of 18010 breast cancer patients. ${ }^{34}$

\section{Predisposition genes}

Approximately $10 \%$ of cutaneous melanomas arise in individuals with a family history of the disease. About $5 \%$ are truly hereditary; ${ }^{35,36}$ in these families predisposition to melanoma is transmitted as an autosomal dominant trait with variable penetrance. ${ }^{37} \mathrm{~A}$ number of these cases, linked to chromosome $9 \mathrm{p} 13.22^{38}$ are caused by mutations in the $p 16$ gene $(C D K N 2 A){ }^{39,40}$ Individuals with multiple dysplastic naevi (dysplastic naevus syndrome, also known as atypical mole syndrome or AMS, are at increased risk of developing melanoma and are frequently observed in familial melanoma kindreds. ${ }^{41,42}$ In families where there is a family history of melanoma and dysplastic naevi, the risk of developing melanoma in susceptible individuals approaches $100 \%$. Not all melanoma-prone families possess dysplastic naevi, so that the concordance of these two syndromes is not absolute. ${ }^{43,44}$ Given the common neural crest origin of uveal and skin melanocytes, any inherited syndrome associated with an increased uveal naevus count may be a precursor for some uveal melanomas. Uveal and conjunctival naevi all occur more commonly in patients with the dysplastic naevus syndrome. ${ }^{45}$ Bataille et al. ${ }^{46}$ examined the skin of 207 consecutive patients with ocular melanoma. Five patients had primary melanoma of the skin (relative risk of cutaneous melanoma 12.5). Furthermore, 3 of these 5 cases also had the AMS phenotype. Similarly in a systematic study of 109 uveal melanoma patients reported by van Hees et al. ${ }^{47} 2$ patients had cutaneous melanomas and 4 had first-degree relatives affected with melanoma. The linking factor in three of the cases was AMS. The coexistence of ocular and cutaneous melanoma in both of these studies supports a predisposition to both types of melanomas in some family cancer syndromes, particularly AMS. Uveal melanoma risk is also related to the density of common naevi in a similar manner to cutaneous melanoma, ${ }^{48}$ and naevi are known to be strongly heritable. ${ }^{49}$

Little is known about the molecular mechanisms involved in the development of uveal melanoma. In addition to the possible involvement of the CDKN2A gene on chromosome 9 , recent work strongly suggests that mutations in the breast cancer susceptibility locus, $B R C A 2$ on chromosome 13 , may also be involved..$^{50}$ Whilst the greatest cancer risks associated with $B R C A 2$ mutations are breast and ovarian cancer, with lifetime risks of $84 \%$ and $27 \%$ respectively, ${ }^{51} 2$ of the 14 breast cancer families linked to $B R C A 2$ reported by Wooster et al..$^{50}$ had cases of ophthalmic cancer, one of which was confirmed as a uveal melanoma. Data to support BRCA2 as a uveal melanoma predisposition gene were presented at a recent meeting of the Breast Cancer Linkage Consortium. ${ }^{52}$ Sinilikova et al. ${ }^{52}$ reported that in a series of 62 ocular melanoma patients selected for a history of breast and ovarian cancer or ocular melanoma, 7 harboured rare germline alterations in BRCA2. All 3 of the patients with pathogenic mutations (5\%) had a history of breast cancer.

Observations from BRCA2-linked breast cancer families suggest that the risk of ocular melanoma is increased 20-fold, although the confidence limits are extremely large. On this basis, and assuming a population frequency of $B R C A 2$ mutations of 1 in 1000 , $B R C A 2$ mutations may account for approximately $2 \%$ of ocular melanoma cases. The possible involvement of $B R C A 2$ in the aetiology of uveal melanomas may underlie the association between this disease and breast and ovarian cancers seen in some patients. BRCA2associated breast cancers have a greater propensity to being higher-grade tumours than sporadic forms of the disease ${ }^{53}$ it is therefore possible that BRCA2-associated ocular melanomas may also have a more aggressive tendency.

Although there is compelling circumstantial evidence implicating CDKN2A in the aetiology of uveal melanomas, there is currently no direct evidence. No mutations were detected in the studies reported by Wang et al..$^{54}$ and Tsao et al..$^{55}$ though these were based on analyses of only 37 and 33 ocular melanoma patients respectively.

Mutations in genes such as $B R C A 2$ are likely to confer a significant risk of uveal melanoma. In addition to this type of susceptibility gene, it is probable that there will be other predisposition genes for ocular melanoma that will confer more modest risks, but which will be more common. Candidates genes in this class are those that affect the host response to exogenous risk factors. Tissue response to ultraviolet irradiation is an important factor in determining melanoma risk and light skin and irides (blue, grey or green) are associated with an increased risk of uveal melanoma. Both of these traits are heritable. 
The genetics of pigmentation are complex. It is known, however, that the relative proportions of phaemomelanin and eumelanin in tissues are regulated by melanocyte stimulating hormone (MSH), which acts via its receptor (MC1R) on melanocytes to increase the synthesis of eumelanin. In mice, mutations at the MC1R gene affect the pattern of melanogenesis, resulting in changes in coat colour. In man, $M C 1 R$ sequence variants cause differences in the binding affinity of the MC1R for $\mathrm{MSH}^{56}$ and are found predominantly in individuals with fair skin and blue eyes. ${ }^{57}$ Furthermore, $M C 1 R$ variants have been shown to confer a 4 -fold increase in risk of melanoma (95\% CI, 1.48-10.35).$^{58}$ It is conceivable that as well as being a risk factor for cutaneous melanoma, mutations in the $M C 1 R$ gene could be a risk factor for ocular melanoma.

\section{Conclusions}

There is now considerable evidence that, like many cancers, a subset of uveal melanomas are caused by an inherited predisposition. Given that the prognosis associated with ocular melanoma is poor, an attractive proposition to reduce morbidity and mortality is to identify these susceptibility genes. This will allow those at risk to be identified and offered targeted surveillance or other measures. Furthermore, the identification of these genes should provide insights into the pathogenesis of uveal melanoma in general. At present the identification of a high-risk group is restricted to small numbers, comprising individuals from $B R C A 2$ families and individuals with the AMS.

\section{References}

1. Osterlind A. Trends in incidence of ocular malignant melanoma in Denmark 1943-1982. Int J Cancer 1987;40:161-4.

2. Swerdlow AJ. Epidemiology of melanoma of the eye in the Oxford Region, 1952-78. Br J Cancer 1983;47:311-3.

3. Parkin DM, Muir CS, Whelan LB, et al. Cancer incidence in five countries. Vol VI. Lyon: International Agency for Research on Cancer, 1992.

4. Jensen OA, Prause JV. Malignant melanomas of the human uvea in Denmark: incidence and 25-year follow up of cases diagnosed between 1943 and 1952. In: Lommadsch PK, Blodi FC. Intraocular tumors. New York: Springer-Verlag, 1983:85-92.

5. Polednak AP, Flannery JT. Brain, other central nervous system, and eye cancer. Cancer 1995;75(Suppl 1):330-7.

6. Egan KM, Seddon JM, Glynn RJ, Gragoudas ES, Albert DM. Epidemiologic aspects of uveal melanoma. Surv Ophthalmol 1988;32:239-51.

7. Shields JA, Shields CL. Intraocular tumors: a text and atlas. Philadelphia: WB Saunders, 1992:45-69.

8. Singh AD, Donoso LA. Genetic aspects of uveal melanoma. In: Shields JA, editor. Update on malignant ocular tumours. Int Ophthalmol Clin 1993;33:47-52.

9. La Vecchia C, Lucchini F, Negri E, Boyle P, Maisonneuve P, Levi F. Trends of cancer mortality in Europe, 1955-1989. IV. Urinary tract, eye, brain and nerves, and thyroid. Eur J Cancer 1992;28A:1210-81.

10. Strickland D, Lee JA. Melanomas of eye: stability of rates. Am J Epidemiol 1981;113:700-2.
11. Raivio I. Uveal melanoma in Finland: an epidemiological, clinical, histological and prognostic study. Acta Ophthalmol Suppl 1977;133:1-64.

12. IARC monographs on the evaluation of carcinogenic risks to humans vol 55. Solar and ultraviolet radiation. Lyon: IARC, 1992.

13. Tucker MA, Shields JA, Hartge P, Augsburger J, Hoover RN, Fraumeni JF Jr. Sunlight exposure as risk factor for intraocular malignant melanoma. N Engl J Med 1985;313:789-92.

14. Tucker MA, Hartge P, Shields JA. Epidemiology of intraocular melanoma. Recent Results Cancer Res 1986;102:159-65.

15. Seddon JM, Gragoudas ES, Glynn RJ, Egan KM, Albert DM, Blitzer PH. Host factors, UV radiation, and risk of uveal melanoma: a case control study. Arch Ophthalmol 1990;108:1274-80.

16. Holly EA, Aston DA, Char DH, Kristiansen JJ, Ahn DK. Uveal melanoma in relation to ultraviolet light exposure and host factors. Cancer Res 1990;50:5773-7.

17. Scotto J, Fraumeni JF Jr, Lee JA. Melanomas of the eye and other noncutaneous sites: epidemiologic aspects. J Natl Cancer Inst 1976;56:489-91.

18. Silcock AQ. Hereditary sarcoma of the eyeball. Trans Pathol Soc Lond 1892;43:140-1.

19. Canning CR, Hungerford J. Familial aveal melanoma. Br J Ophthalmol 1988;72:241-3.

20. Singh AD, Shields CL, De Potter P, Shields JA, Trock B, Cater J, Pastore D. Familial uveal melanoma: clinical observations on 56 patients. Arch Ophthalmol 1996;114:392-9.

21. Spe TW. Uveal malignant melanoma and von Recklinghausen's neurofibromatosis. Cancer 1988;62:812-7.

22. Kedem A, Even Paz Z, Freund M. Basal cell nevus syndrome associated with malignant melanoma of the iris. Dermatologica 1970;140:99-106.

23. Singh AD, Wang MX, Donoso LA, Shields CL, Potter PD, Shields JA, et al. Familial uveal melanoma. III. Is the occurrence of familial uveal melanoma coincidental? Arch Ophthalmol 1996;114:1101-4.

24. Prause JV, Jensen OA, Eisgart F, Hansen WW, Kieffer M. Bilateral diffuse malignant melanoma of the uvea associated with large cell carcinoma, giant cell type of the lung. Ophthalmologica 1984;189:221-8.

25. Serogard S, Daunius C, Popovic V. Two cases of primary bilateral malignant melanoma of the choroid. Br J Ophthalmol 1988;72:244-5.

26. Zygulska-March H, Slomska J, Heitzman J. Szesc prypadkow obuocznego czerniaka blong naczyniowej. Klin Ocza 1992;94:157-8.

27. Schammas HF, Watzke RC. Bilateral choroidal melanomas. AMA Arch Ophthalmol 1977;95:617-23.

28. Jay M, McCartney AC. Familial malignant melanoma of the uvea and p53: a Victorian detective story. Surv Ophthalmol 1993;37:457-62.

29. Mullaney J, Mooney D, O'Connor M, McDonald GS. Bilateral ovarian carcinoma with bilateral uveal melanoma. $\mathrm{Br} \mathrm{J}$ Ophthalmol 1984;68:261-7.

30. Rednam KR, Jampol LM, Levine RA, Goldberg MF. Uveal melanoma in association with multiple malignancies: a case report and review. Retina 1981;1:100-6.

31. Tucker MA, Boice JD Jr, Hoffman DA. Second cancer following cutaneous melanoma and cancers of the brain, thyroid, connective tissue, bone, and eye in Connecticut, 1935-82. Natl Cancer Inst Monogr 1985;68:161-89.

32. Travis LB, Curtis RE, Boice JD Jr, Platz CE, Hankey BF, Fraumeni JF Jr. Second malignant neoplasms among long term survivors of ovarian cancer. Cancer Res 1996;56:1564-70. 
33. Osterlind A, Olsen JH, Lynge E, Ewertz M. Second cancer following cutaneous melanoma and cancers of the brain, thyroid, connective tissue, bone, and eye in Denmark, 1943-80. Natl Cancer Inst Monogr 1985;68:361-88.

34. Schoenberg BS, Christine BW. Malignant melanoma associated with breast cancer. South Med J 1980;73:1493-7.

35. Greene MH, Fraumeni JF Jr. The hereditary variant of malignant melanoma. In: Clark WH Jr, Goldman LI, Mastrangelo MJ, editors. Human malignant melanoma. New York: Grune and Stratton, 1979:139-66.

36. Goldstein AM, Tucker MA. Genetic epidemiology of familial melanoma. Dermatol Clin 1995;13:605-12.

37. Cannon-Albright LA, Meyer LJ, Goldgar DE, Lewis CM, McWhorter WP, Jost M, et al. Penetrance and expressivity of the chromosome 9p melanoma susceptibility locus (MLM). Cancer Res 1994;54:6041-4.

38. Cannon-Albright L, Goldgar DE, Meyer LJ, et al. Assignment of a locus for familial melanoma, MLM, to chromosome 9p13-p22. Science 1993;258:1148-52.

39. Hussussian CJ, Struewing JP, Goldstein A, et al. Germline p16 mutations in familial melanoma. Nature Genet 1994;8:15-21.

40. Kamb A, Shattuck-Eidens D, Liu Q, et al. Analysis of the p16 gene (CDKN2) as a candidate for the chromosome $9 p$ melanoma susceptibility locus. Nature Genet 1994;8:22-6.

41. Kraemer KH, Greene MH. Dysplastic nevus syndrome: familial and sporadic precursors of cutaneous melanoma Dermatol Clin 1985;3:225-37.

42. Seykora J, Elder D. Dysplastic nevi and other risk markers for melanoma. Semin Oncol 1996;22:682-7.

43. Goldgar DE, Cannon Albright LA, Meyer LJ, Piepkorn MW, Zone JJ, Skolnick MH. Inheritance of nevus number and size in melanoma and dysplastic nevus syndrome kindreds. J Natl Cancer Inst 1991;83:1726-33.

44. Traupe H, Macher E, Hamm H, Happle R. Mutation rate estimates are not compatible with autosomal dominant inheritance of the dysplastic nevus 'syndrome'. Am J Med Genet 1989;32:155-7.

45. Rodriguez-Sairs RS. Ocular findings in patients with dysplastic nevus syndrome. Ophthalmology 1986;93:661-5.

46. Bataille V, Pinney E, Hungerford JL, Cuzick J, Bishop DT, Newton JA. Five cases of coexisting primary ocular and cutaneous melanoma. Arch Dermatol 1993;129:1998-201.
47. van Hees CL, Jager MJ, Bleeker JC, Kemme H, Bergman W. Occurrence of cutaneous and uveal melanoma in patients with uveal melanoma and their first degree relatives. Melanoma Res 1998;8:175-80.

48. Bataille V, Sasieni P, Cusick J, Hungerford JL, Swerdlow A, Newton-Bishop JA. Risk of ocular melanoma in relationship to cutaneous and iris naevi. Int J Cancer 1995;60:622-6.

49. Easton DF, Cox GM, Macdonald AM, Ponder BAJ. Genetic susceptibility to naevi: a twin study. Br J Cancer 1991;64:1164-7.

50. Wooster R, Neuhausen S, Mangion J, et al. Localisation of a breast cancer susceptibility gene to chromosome 13q12-q13. Science 1994;265:2088-90.

51. Ford D, Easton DF, Stratton M, et al. Genetic heterogeneity and penetrance analysis of the BRCA1 and BRCA2 genes in breast cancer families. The Breast Cancer Linkage Consortium. Am J Hum Genet 1998;62:676-89.

52. Sinilikova OM, Egan KM, Quinn JL, et al. Germline BRCA2 sequence variants in patients with ocular melanoma. BCLC Meeting Dublin 1998. Abstract 14.5.

53. Pathology of familial breast cancer: differences between breast cancers in carriers of BRCA1 or BRCA2 mutations and sporadic cases. The Breast Cancer Linkage Consortium. Lancet 1997;347:1505-10.

54. Wang X, Egan KM, Gragoudas ES, Kelsey KT. Constitutional alterations in p16 in patients with uveal melanoma. Melanoma Res 1996;6:405-10.

55. Tsao H, Benoit E, Sober AJ, Thiele C, Haluska FG. Novel mutations in the $\mathrm{p} 16 / \mathrm{CDKN} 2 \mathrm{~A}$ binding region of the cyclindependent kinase-4 gene. Cancer Res 1998;58:109-13.

56. Valverde P, Healey E, Jackson I, Rees JL, Thody AJ. Variants of the melanocyte stimulating hormone receptor gene are associated with red hair and fair skin in humans. Nature Genet 1995;11:328-30.

57. Xu X, Tornwall M, Lars-Gustar L, Chhajlani V. Val92met variant of the melanocyte stimulating hormone receptor gene. Nature Genet 1996;14:384.

58. Valverde P, Healy E, Sikkink S, Haldane F, Thody AJ, Carothers A, Jackson IJ, Rees JL. The Asp84Glu variant of the melanocortin 1 receptor $(\mathrm{MC} 1 \mathrm{R})$ is associated with melanoma. Hum Mol Genet 1996;5:1663-6. 